\title{
Science and religion: what is at stake?
}

\author{
Wolff-Michael Roth
}

Received: 7 August 2009/Accepted: 7 August 2009/Published online: 16 September 2009

(C) Springer Science+Business Media B.V. 2009

\begin{abstract}
There are some who experience irreconcilable differences between their religious beliefs concerning a world created as is, on the one hand, and a scientific view of the world that has developed by means of natural evolution over billions of years, on the other hand. In this special issue, scholars from very different religions, backgrounds, and academic fields contribute to the debate with contributions to (a) a forum based on philosophical argumentation, (b) a collection of original studies and approaches from different parts of the globe concerning the relation between the two domains, and (c) a forum concerning the conversations and writings of a high school student concerning his way of reconciling science and religion. Together, these three parts of this special issue on the topic of science and religion constitute within themselves and across the collection a highly variegated, multicolored tapestry of beliefs, voices, cultures, and countries that explode any narrowly defined opposition between the two domains particularly concerning the theory of evolution and belief in creation (intelligent design). In this introduction, I articulate the questions (always) to come, the power/knowledge dimension underlying the current struggle observable between the two forms of human experience in the public domain, sketch the contents of the issue as a whole, and provide some outline for possible future directions in our work.
\end{abstract}

Keywords Science and religion - Power/knowledge $\cdot$ Ruling relations $\cdot$ Experience . Fullness of life - Temporality

[F]or a religion that without hesitation announces war to reason will, in the long run, not hold up to it.

$$
\text { (Kant 1956, p. 657, my translation) }
$$

In this introduction to the special issue, I begin by articulating questions about science and religion using a concrete case of one of my high school physics student, who also became a research collaborator, and by moving to a philosophical grounding of the question of

W.-M. Roth $(\bowtie)$

MacLaurin Building A548, University of Victoria, Victoria, BC V8W 3N4, Canada

e-mail: mroth@uvic.ca 
science and religion. As the areas of friction and turbulence occur particularly around the relative merits of evolution theory and creationist belief in intelligent design, I lay the groundwork for studying the power/knowledge relation that is at stake in the formulation of science curriculum content (knowledge) to be taught. I continue by sketching the structure of this special issue devoted to science and religion and conclude with (a) an expansion of efforts to understand science and religion as one-sided expression of the totality of life, (b) a call for research on the public struggle of (some) science and (some) religions (religious factions) from power/knowledge perspective. I end with a call for continued dialogue that should contribute to increase understanding on both of the opposing sides.

\section{The questions to come}

In 1992, Todd, then a 17-year-old high school student entitled and essay that wrote concerning knowledge and the world "De Luce Loquat".

"And, God said, Let there be light: and there was light. And God saw the light: that it was good." As far as we can remember man realized that there was something that allowed us to perceive the world in which we lived, this something was also a provider of heat, man called this thing light. How much more do we really know about light than we did in the ancient world? Both societies knows of its existence, neither can explain where it came from or what it is made of. The best explanation of its existence, which is the only one that I am aware of is that God willed it to exist and so it did. The fact that it is good comes most likely from the second property, the ability to provide heat or energy, a necessary substance in our world and the ancient world for man's existence. Since it was useful to man and helped him to survive it is therefore a good thing. Many philosophers over the ages attempted to explain the ways in which light behaved. In actuality, creating a means by which to explain the way in which we perceive things, a difficult task to say the least. By the twentieth century after two major ideas had been at odds for ages, finally both were accepted for there validates but there faults were also noted. These theories included the particle nature of light, and the wave nature of light, in connection with these theories comes the particle and wave nature of matter, in particular subatomic matter.

In this beginning of his essay, the young man speaks of God and about the origin of some of the stuff that makes the world we know. God willed light. It came to exist and became a fact to man. Todd also wrote about the difficulties the moderns had in dealing with the nature of light, which was theorized in one of two ways that were at odds. God and science co-exist. They co-exist even in the face of the fact that God created the universe that science explains. God and science are at peace in the discourses that Todd uses to talk about the major ethical challenges humanity faced at the time, challenges that only became more serious, including the ethical challenges around cloning, medical procedures, and the environment. They co-exist to the present day, as I could testify when I recently met up with Todd again, who has become one of a handful of Canadian pediatric nephrologists who also holds a Ph.D. in microbiology. That is, in this particular instance, there appears to be no conflict between a deep religious commitment, on the one hand, and a highly successful trajectory in the "science pipeline," on the other hand.

The signs for a potentially successful dialogue between scientific interest and inclination, on the one hand, and a deep commitment to the belief in a supreme being, on the other hand, may have been present while Todd still attended high school and during the months 
following successful graduation. During this time, he participated in a study of scientific and religious discourses among high school students and co-authored a scientific article (Roth and Alexander 1997), early versions of which he collaborated while presenting our work at international conferences. Whereas during eleventh grade he talked about the existence of scientific truths, the absoluteness and infallibility of scientific knowledge, and the possibility of objectivity, his subsequent discourse was radically different. He talked about science as an effort in the construction of explanatory schemes that tend to be vetted in the collective forum of the scientific community. Thus, although he talked about a world that is experientially real, he suggested that it is impossible to know such a world as it really is. He argued that constructions are useful in dealing with this world, but we can never know the functional relationship between this knowledge and the world.

With respect to religion, Todd differentiated between organized churches and their socially constructed systems of rules, on the one hand, and the irremediable nature of truth concerning the personal experience of revelation and God, on the other hand. Because the notion of social construction allows multiple viewpoints of the same phenomenon, Todd did not experience conflict bringing the two realms together in the process of rational discourse. He could draw on a variety of discursive repertoires without experiencing conflict for answers to difficult decisions. The religious discourse provided Todd with an important spiritual resource for making difficult decisions in this world.

Todd as many other students and adults, easily navigates between his inclination for science and scientific research, on the one hand, and his religion and religious beliefs, on the other hand. The question at issue is why such individuals can integrate their deep religious beliefs with an illustrious career in science whereas others see in some of science a threat to their beliefs - as in the case of the evolution-creation debate. Fundamentally, science and religion can be understood as two sets of fundamental and inseparable human practices and belief systems (Durkheim 1897-1898). The two knowledge/belief and practice systems have a long history together, unfolding in parallel, intersecting processes that at times collaborate at other times compete. The latter is often exemplified in the struggle opposing the (Catholic) Church and Galileo Galilei and their opposing views on the structure of the universe. At times, religious and even occult practices coexist with the best in scientific practices in the same person, such as in the figure of Sir Isaac Newton.

The term science can be traced etymologically to the Latin verb scīre, to know. But the roots of the word are deeper, going back to the Indo-Germanic *sĕk-, to cut, to separate and giving rise to the words sign (via signum) and consciousness (via con-, together, and scìre). Consciousness means knowing together, the knowledge that we share; it is always consciousness-for-the-other as much as it is consciousness-for-oneself (Vygotsky 1986). In this, there is a common thread to religion, though it may appear at first as a far stretch. Although doubtful, most scholars appear to agree that religion derives from the Latin religāre, to bind, via the Latin religiō, reverence for God or gods, and the old French, religion, religious community. This is also the sense in which Kant takes the term religion, as a community of believers. As with consciousness, religion makes salient the community of knowers (of revelation) and of practice. This relation is the effect of fundamental forces of the earth:

So we must once again acknowledge that religion, which is common to human beings and animals, occupies territory only because it depends on the raw aesthetic and territorializing factor as its necessary condition. It is this factor that at the same time organizes the functions of the milieu into occupations and binds the forces of chaos in rites and religions, which are forces of the earth. Territorializing marks 
simultaneously develop into motifs and counterpoints, and reorganize functions and regroup forces. But by virtue of this, the territory already unleashes something that will surpass it. (Deleuze and Guattari 1987, pp. 321-322).

Are the (court) battles and public arguments between the religious right and defenders of evolution theory ways of marking the territory? The terms evolution, creation, and intelligent design already constitute such markers that have become motifs and counterpoints, with their organizing function separating what we know as the religious right and the scientists into different camps. What will this territory unleash that ultimately will surpass it? But this may not be the right question; in fact, given the open nature of human life with respect to the future, which always further removes into the future the closer we think we are, the right question to be asked may always be one to come as successive attempts in answering exhibit the inadequacies of our questioning. One of the important dimensions in the relation between the two domains, however, appears to be the question about power and knowledge, two theoretical concepts that cannot be thought independently as I sketch in the following section.

\section{Science and religion: about power/knowledge}

Ardent pro-evolutionists sometimes charge that fundamentalist creationists are not subject to reason and that they are not open to the facts and rational explanations thereof. But already more than 100 years ago, the father of sociology, Émile Durkheim (1897-1898) in a treatise on religious phenomena, suggested that nature cannot be used to decide between the most idealist scientist and the most uncultivated person:

Let us for the moment suppose the realization of the most perfect science that the most intransigent idealist can think of; let is imagine the world completely translated into clear and defined concepts. To whoever had such an integral science there would evidently remain no mystery in the world; the entire reality would appear to him in plain light because it would be reduced entirely to a system of manipulatable notions that he would hold, so to speak, in the palm of his hand. Well, a completely uncultivated mind would be in an analogues state for the opposite reasons. To him, everything is easily explained, because for him to the universe, or at least the part of the universe that is of interest to him-everything is expressed in a system of internal states that he handles with the same ease. ( $\uparrow 9$, my translation).

Science and religion, which the zealots say is not based on reason, therefore have more in common than they are different. This is no clearer today, where the creationists emphasize the fact that evolution is a theory rather than a fact. This led me some time ago to write into my research notebook the sentence of a symmetry between the fervent participants on both sides of the debate: "Some scientists are as religious about evolution as some religious people are scientific about creation." In fact, those scientists are like the Crusaders-who went to war against the heathens that had dared to occupy Jerusalem and the Holy Land-but the modern day Crusaders are going to war against the fundamentalist right, who dared occupying its territory in the curriculum. However, especially the rationalist cannot eradicate the religious (though s/he might refuse to study it as a scientific phenomenon), because religion, "as consciousness of absolute Being as such" (Hegel $1806 / 1969$, p. 495 , original emphasis, my translation) clearly is a phenomenon produced by and in human consciousness just as much as consciousness, self-consciousness, reason, and 
mind: "In religion, the self-knowing Spirit is its own pure self-consciousness without mediation" (p. 496). Because religion is as much the result of consciousness as reason, "The rationalist [in matters of belief]," Kant (1956) says, "has to keep within the boundaries of human understanding. As a naturalist he will never dispute the inner possibility of revelation nor the necessity of a revelation as a divine means to the introduction of the true religion, because in these matters no human being can get anywhere by means of reason" (p. 823).

Why do scientists not just shrug shoulders when it comes to creation or intelligent design in the way they shrug shoulders when the talk comes to cold fusion, by and large a discredited part of science? The fact that they do engage with the creationists shows that there are stakes of a different nature than the ones concerning scientific hoaxes. Evidently, the battleground includes curricula, schools, and what gets taught in science classrooms. What gets taught is knowledge; and, as we know science the cogent analyses Michel Foucault (1975) provided concerning the relationship between physical and mental discipline knowledge is irremediably related to power. This power is not a thing that one can own or not own. There are not people who have power over others. There is symmetry where those involved on the receiving end of ruling relations contribute to its existence. Thus, "this power," Foucault writes, "is not applicable purely and simply like an obligation or an interdiction to those 'who do not have it'; it invests them, passes by and through them; it is supported by them just as they, in their struggle against it, take support in their turn over the holds that it exercises over them" (p. 35).

These struggles of power/knowledge play themselves out not only between individuals within collectives but also within individuals, who, in the public arena, acknowledge belongingness to one or the other community. Thus, Preston, one of Todd's classmates, articulated time and again that at issue is not merely knowledge but that those who abandoned God had an easier time acquiring scientific knowledge: "I think that more people can be drawn towards science as it really is, because it is easier to believe, rather than religion...it grabs the minds of atheists rather than...mine, because I am very religious." Preston, who articulated beliefs in a rather recent creation of the universe (about 50,000 years) frequently talked about the public sphere, where he said to have debated the issue of science and religion with other classmates in his dorm. In these debates, he linked science and atheism, which combine to confront the believer:

People assume that there is a God, because more, because people believe it, they start to believe other people. Like if, lets say, if I was to say really good points about religion and you was to say really good points about physics, but I assume, and you assume that there is no God, and I say that there is a God, and there is an atheist right there, who do you think he will believe?

He suggested that his science teachers generally and the physics teacher interviewing him specifically were atheists.

It has to be that every person in this school I noticed, is a complete atheist. Like if you look in chapel, you see everyone's head is like up like this, they look around. They don't really believe at all in religion, because more or less they have gone to science classes, they believe more in science. They don't want to believe in God, so they head toward science that, because that's their future, they need a future in science. 
In these interview excerpts, we see how the battleground takes shape in the discourse of this student, which is a realization of discursive possibilities that already exist at the cultural level. They are part of the repertoire that we come to hear from the religious right. These battlegrounds territorialize and leave their marks within the individuals, they are not to be thought of as characteristic of the public sphere alone. As Foucault would say, there is always a relation between the public and the private, whereby discipline comes to be produced both publicly and privately. The lack of religious discipline is observable in the failure to lower the gaze in chapel, a result of having gone to science classes, where atheists teach and where atheists succeed. Science grabs the minds of atheists and it produces the minds of atheists, and their resistance to God can be seen in their comportment.

Preston is not so far off with his idea concerning the production and reproduction of knowledge, though this cuts both ways, not only in the direction of science (and atheists). Thus, from a cultural-historical social psychological perspective, any higher cognitive function exists as a form of societal relation (Vygotsky 1978). Participating in societal (institutional, ruling) relations mediates the development of the individual mind, itself constitutive of societal (institutional, ruling) relations and their cultural-historical development. Participating in public religious practices not only allows individuals to acquire these practices but also the ideal objects that come with them, that is, the individual beliefs. In this way, not only is mind in society, as Vygotsky's book title suggests, but also society is in the mind. Returning to Preston, we find religion and science to be modeled according to the same theme: Taking science courses from atheist teachers produces more atheists, and those with predilections to be atheists have an easier time being good at science. As a result, "every person in this school...is a complete atheist." Institutional relations, that is, relations of power, produce specific forms of knowledge, and specific forms of knowledge produce specific forms of power and institutional relations. There is a microphysics at work that would be interesting to study, both as the phenomenon plays itself out within the institutional relations and how these come to be inscribed in the individual body, subjected to a discipline that produces self-discipline and specific forms of disciplinary knowledge, whether this is religious knowledge or scientific knowledge.

The issues of power/knowledge are made more complicated because of the relation between church and state, where existing institutional relations might reinforce one or the other. This is so even in states, including the US, where the separation of church and state is derived from the constitution, but where politicians up to the president (e.g., G. W. Bush) connect the two. God comes to be invoked wherever opportune ("God bless America"), even though not every American is religious and even though there are religions that do not have a god. But state and federal politicians shape the curriculum, so that particular religious predilections come to be enshrined in the curriculum. The worries about those holding the purse strings financing science and also having religious commitments inconsistent or at least "coy" about evolution also reach into Canada, where the minister responsible for science, Gary Goodyear, refused to answer questions "about whether he believed in evolution" (CBC 2009, -2).

On the other hand, there are democratic states and jurisdictions where religion is part of the official curriculum and yet there are no such micropolitics concerning the question about evolution, creation, and intelligent design that mark the debate in the US. Thus, in the Canadian province of Ontario, religion is included in the curriculum because "the nature of our society, of the individual, of the curriculum, and of the contemporary world make it appropriate and beneficial for the public schools to incorporate education about religion into the curriculum" (OMoE 2009, Part B $\mid 1$ ). Including religion allows students 
"to acquire information about and develop respect for religions that are practised in Ontario and throughout the world" (Part B -1). Similarly, in the Canadian province of Newfoundland, religious education is part of the official curriculum. This non-confessional curriculum focusing on a variety of religions "enables and encourages students to grow spiritually and morally into informed, caring and contributing members of society. Students develop an appreciation for their own beliefs and values, and the beliefs and values of others. They acquire an understanding of the contribution that religions make to human life" (N\&LDoE 2009, p. 58).

The fact that religion is part of the regular curriculum in secular jurisdictions that practice a separation of church and state (Germany, Ontario, Newfoundland) shows that it is possible to include both science and religion and therefore avenues to teach both evolution and creation. Moreover, the often-interdenominational approaches to religious instruction encourage the development of an acceptance of the otherness of the Other with respect to religious commitments and beliefs. Such approaches have the potential to lead to a richer tapestry of the relation of science and religion than the simple and simplistic opposition of evolution and creation (intelligent design) may lead us to believe. The richness of such tapestry clearly is embodied in the sometimes-subtle differences and similarities across the contributions to this special issue as a whole.

\section{Overview of contributions}

Historically, the special issue began with the submission of a draft manuscript on the part of John Staver. The editors-in-chief made the decision to publish a revised version and to ask a number of scholars to write commentaries. Eventually emerged the idea to develop a special issue around science and religion. This special issue contains three parts, two forums and a section with independent contributions and a commentary.

The first forum centers on the feature article by John Staver, who, as a practicing Christian, seeks to reconcile any differences and conflicts that might exist between science and religion. His answer fundamentally consists of the proposal that science and religion adhere to constructivism and abandon claims to Truth. Scientists would merely relinquish the search for nature as it "really" is but would retain everything else that currently characterizes it. Those believers who hold that religion has direct access to reality would come to understand that their God never revealed the truth of nature but rather revealed the Truth about conducting one's life. Six scholars from varying backgrounds and with various positions with respect to religion provide commentaries to the lead article. Thus, the forum includes, in alphabetical order: Baskhar Upadhyay, a science educator of Nepalese origin who provides his commentary from a Hindu perspective; Eliane Brigida Morais Falcão, a Brazilian science educator interested in how fundamentalist Christian beliefs mediate the process of becoming a science educator; Nidhal Guessoum, a professor of physics at the American University of Sharjah (United Arab Emirates) who provides a perspective on Staver's article from Islam; Ed Lehner, a science educator in the Bronx, reflects on the relation of science and religion from his position as a practicing Christian in the Protestant tradition; Colette Murphy, Ivor Hickey, and Jim Beggs are scientists turned science educators from Northern Ireland born into Catholic and Protestant families, who take a look at the attendant issue through the lens of their experiences of the "Troubles" in the country that for decades confronted the members of the two Christian denominations; and Michael Reiss, a British science educator and pastor-himself embroiled in controversy over comments about religion and science education that forced him to resign from a position of 
the British Royal Society following the pressure from scientists-concludes this forum. Readers will notice upon reading the commentaries that despite their different religious commitments, there are many common threads in their articulation of disagreements with the feature article. The most dominant among these threads appears to be the conclusion that constructivism, offered by Staver as the solution to the relation of science and religion, will not be able to live up to the promises that the author ascribes to this epistemology.

The second section of this special issue consists of individual contributions again from very different experiential backgrounds and positions. Charbel N. El-Hani (professor of history, philosophy, and biology teaching) and Claudia Sepulveda (professor of education) report a study in which they map the conceptions of nature that Brazilian protestant preservice biology teachers articulated. The authors identify two groups, one consisting of individuals whose religious worldviews are more compatible with science whereas the other group consisted of individuals "largely inclined to repudiate scientific knowledge." Nasser Mansour, an Egyptian scholar currently working in the UK, analyzes science teachers' interpretations of Islamic culture related to science education and compares it to Islamic epistemology and ontology of science. Pongprapan Pongsophon is a Thai science educator who attempts to improve Thai pre-service teachers' understanding of the relationship between science and religion through drama performances. K. Helmut Reich, an eminent and widely published scholar at the interface between science and religion contributes a commentary in which he calls for a broad-based dialogue that takes into account the most promising ontologies, epistemologies, and logics.

The first forum discusses the relation of science and religion at a philosophical level drawing on scientific, religious, and philosophical texts in support of the respective arguments. In the second part of this special issue, Charbel N. El-Hani and Claudia Sepulveda, Nasser Mansour, and Pongprapan Pongsophon provide their readings of interview transcripts that they collected from students in Brazil, Egypt, and Thailand. They provide a single perspective on the data sources. I chose a different orientation for the third forum, which centers on a set of data that I collected in the early 1990s over a 15-month period covering two school years among high school physics students. One of these students had become my collaborator and co-author of a manuscript that took a discourse analytic perspective on the scientific and religious discourses (Roth and Alexander 1997). The contributors to this second forum, the four participants in a seminar on current educational discourses, show how the data support the claims that there are more issues than those of cognitive nature that need to be considered when dealing with the relation of science and religion in the lived experience of real persons. Vivian M. Collyer shows that the discourse about the two cultural domains are shaped by the Other to whom the communication is addressed and that there are differences with respect to the addressee when the communication is written or oral. Norah I. McRae shows that in addition to the interpretive repertoires a person deploys when talking about science and religion, we also need to consider emotion and its role as a mediational moment in the life of the person. Lisa J. Starr takes a constructivist perspective to show the tensions between scientific and religious forms of knowledge with respect to signification and the identity of the person involved. This forum concludes with a commentary on the three analyses provided by Pei-Ling Hsu.

This special issue on the relationship between science and religion is special in many ways. First, it includes voices from around the globe and very different religions, voices that are all too often excluded from our journals because of cultural and linguistic differences that do not give equal opportunities to Others in the competition for the few spots in the major journals' pages. Second, it uses very different formats and perspectives, for 
example, a philosophical debate with the proponent of a particular way of resolving science-religion relations (Staver) when there are conflicts between the two. Then there are a collection of reports on pre/service teachers from Brazil, Egypt, and Thailand. Finally, there is a symposium where different authors take a look at the same data sources concerning essays and conversations pertinent to the topic. The special issue therefore is a reflection of the manifold nature of the conversations around science and religion, thereby exploding the often-narrow argument over evolution versus creation (intelligent design). Third, there are different types of articles coming from the same country, culture, or religion but contributing either as commentary in a forum or as report of a case study. Thus, there is a Muslim commentary (Guessoum) and a report on Muslim teachers (Mansour), there are Protestant voices among the lead article and commentaries (Hickey, Lehner, Reich, Reiss, Staver), and a report on the beliefs of Protestant teachers in Brazil (ElHani, Sepulveda). From Asia, there is a Hindu commentary (Upadhyay) and a report on beliefs among Buddhist Thai (Pongsophon). This mix of different standpoints contributes to the multidimensional tapestry of discourses on science and religion.

\section{Future directions...}

Once readers will have read the contributions to this special issue, they might ask: "Where does all of this lead us?," a question that can be split into "What does this mean for theorizing scientific and religious experience?" and "What might we do next in the study of the relation of science and religion in everyday life?" The questions are only temporary, for the real questions, as the title of the first section (in reference to French philosophy of difference) suggests, are forever to come (Fr. à-venir), are forever in the future (Fr. avenir) because they, as any possible response, are inherently undecidable and impossible. The possible impossibility of a unification of science and religion: because it may be the test of the impossibility, where "language does not speak, it is, in it nothing begins, nothing can be said, but it is always new and always begins all over again" (Blanchot 1959, p. 294, my translation). In this final section, I sketch, in the manner of Jacques Derrida, ever so briefly, always and inherently insufficiently, some possible avenues and future directions that the current public debate has not yet charted.

\section{...in Theorizing Scientific and Religious Experience}

We can do what we intend to do, but we cannot intend our intentions.

(Müller 1981, p. 300, my translation, original emphasis)

Explaining to the Committee on Educational Policy his comment that education was a "rip off" from a student viewpoint, the anthropologist and philosopher Gregory Bateson (1980) suggested that a number of premises on which (university) education is built are obsolete. These obsolete notions include the separation of mind and matter, the physicalism of the metaphors used for mental phenomena (power, social forces, energy), and an anti-aesthetic assumption that all phenomena can and shall be studied and evaluated-in the wake of Bacon, Locke, and Newton-in quantitative terms. Clearly, Bateson speaks to particular form of rationalist thought. As a base for religion, Bateson, these notions are intolerable, obsolete, and can only generate "dark Satanic mills" (p. 236). He deplores:

As in religion, the constitutional guarantees of "religious freedom" seem to promote similar exaggerations: a strange, totally secular Protestantism, a wide spectrum of 
magical cults, and total religious ignorance. It is no accident that simultaneously the Roman Catholic Church is giving up the use of Latin, while the rising generation is learning to chant in Sanskrit! (p. 236).

Today, he might have added the religious right that ventures onto the grounds of science, and, using its own means, to fight a battle that Immanuel Kant, in the introductory quote, suggested it cannot but loose. Bateson has other things to say, and these concern science that misconceives itself. One of his sections in the chapter "What every Schoolboy Knows..." is entitled "Science Never Proves Anything." In it, he suggests something that not all scientists heed all of the time: "science probes; it does not prove" (p. 30). "As a method of perception - and that is all science can claim to be-science, like all other methods of perception, is limited in its ability to collect the outward and visible signs of whatever may be the truth" (p. 30). Proof, therefore, is possible only in the realm of totally abstract tautology. What ways are there to understand these differences in perceptions specifically and in scientific and religious experience more generally?

In Germany, there exists a long tradition of encounters that brings together science and theology in the Forschungsstätte der Evangelischen Studiengemeinschaft founded in 1957/ 1958. One contribution to its discussions in particular shows how the modalities of time in the sciences and in religion are radically different leading to very different experiences (Müller 1974), where I understand the term experience comprehensively to include those of spiritual, emotional, and other forms that are not measurable by scientific (objective) instrumentation. Thus, the sciences are concerned with objectifiable modalities of time, essentially given by the past, present, and future as they appear in the present. These modalities are characteristic of the horizon circumscribing agency and reflection. These modalities are typical of intention, control, and agency: we can to do what we intend to do. The seat of intention and agency is the I. The horizon of religious experience, however, is the feeling of being-affected, which takes place within the modalities of the past (of the past, present, and future) and of the future (of the past, present, and future). These modalities are associated with the givenness of life: we cannot intend our intentions. The seat of this modality is the Self in its constitutive relationship to the Other. This Self is the origin and source of the I. "The difference between I and Self essentially is the difference between that which in our consciousness determines our agency and that which determines consciousness out of the subconscious" (Müller 1981, p. 300). As subjects (from Lat. subject-us, past participle of subjicěre, to throw, jacĕre, + down, sub-), we are affected; and being-affected is the experience of radical passivity, thrownness and givenness, experiences thematized and explained in different ways and by different means in religion (and philosophy). Much of the current confusion in the debate of science versus religion appears to arise from a conflation of the I and the Self.

Science and religion, therefore, are different because of the different forms of experience and modalities of temporality that characterize them. Evolution, as described by biologists, appears in the temporal modality characteristic of the sciences, the presence of the past, present, and future. The construction of theories such as that of evolution is based on regularities, which occur in time, such that lawfulness of science is tied to a particular modality of time. Thrownness, the experience of our unwilled presence in the world (humans are creatures, a term that has the same etymological roots as create, creation, and creator), however, is part of being-affected, an experience that has no place in science because of its singular nature and for which science has no means of dealing with. Just as Todd made thematic in the course of our collaboration, his singular experience of God and his inclination to science could not be reduced to each other though both are integral parts of the fullness of 
his life. It is precisely this fullness of life that we need to consider to better understand both sides of the debate, struggle, and contest. In life, we find ourselves as creatures, that is, as the etymology of the term suggests, created beings, that is, beings that have been given a life rather than having intended it. This nature of being a creature poses, as already the title of Müller's (1981) text suggests, a challenge to both, science and theology.

Life, in which we find ourselves and that has been given to us, is once-occurrent: "neither theoretical cognition nor aesthetic intuition can provide an approach to the onceoccurrent real Being of an event, for there is no unity and interpenetration between the content/sense (a product) and the act (an actual historical performance)...in the course of establishing meaning and seeing" (Bakhtin 1993, p. 18). Only in and out of the actually performed act can this once-occurrent being understood in its concrete actuality. This realization is the common point to much of ethico-moral philosophy reaching from dialectical materialist Mikhail Bakhtin to Emmanuel Levinas and Paul Ricœur, from the Jewish and Roman Catholic faiths, respectively. It therefore is also the place where religion may come into play, independent of its particulars.

In attempting to come to grips with the question of science, religion, and Truth in the face of scientific understandings of the cosmos and evolution A. M. Klaus Müller (1981), then a professor of theoretical physics and a practicing Lutheran Protestant, suggests that reading the Bible literally or reinterpreting it to make it consistent with science cannot be a viable approach. Reading the Bible non-literally as an articulation of eternal Truth may be an easy solution to the question of its relation to science, but does not go to the heart of its real function: a catalyst that can bring about an experience, testimony, revelation, and the promise of salvation, that is, Truth as it had been accessible to others prior to the existence of the New Testament (e.g., to Jesus, Paul, Peter).

We cannot understand science out of religion or religion out of science. Both domains of experience are integral part of life as a whole. Both are but one-sided expressions of the totality of life, which itself cannot be determined from one of its expressions. Paraphrasing Karl Marx and Friedrich Engels (1969) we might say that it is life that determines consciousness, not religious or scientific consciousness that determines life. Either domain of thought is but a disappearing moment in the total life of the individual. To better understand the relation between the two, therefore, we must not attempt to reduce one to the other but to understand both as moments of a larger whole, which is the totality of life.

\section{...in Studying the Relation of Science and Religion in Everyday Life}

In the interim before coming to a more comprehensive understanding of the totality of human life, and out of it science and religion as one-sided expressions, we may conduct research on the relation between the realms of science and religion in the public space. Being a researcher who has extensively studied learning in and of science, more than contributing to and thereby fueling the debate whether creation should be taught or ought to be banned from the school curriculum, it would be interesting for me to see the emergence of studies that focus on the apparent battle from a Foucauldian perspective. Thus, rather than finding out who has the upper hand in this or that court, it would be interesting to study the microphysics of power:

The study of this microphysics of power [which the state apparatus and institutions put into play] supposes that the power that exhibits itself is not thought as a property, but as a strategy, that the effects of domination are not attributed to an "appropriation," but to dispositions, maneuvers, tactics, techniques, workings. It supposes 
rather that one has to decipher in it a network of relations always under tension, always in action rather than a privilege that one could hold, that one take the model of the perpetual battle rather than a contract that brings about a cessation or a conquest that takes over a domain. (Foucault 1975, p. 35, my translation).

What does science have to loose or gain if it abandons the rejection of creation and intelligent design in the classroom? What does the fundamentalist right have to loose or gain by not having creation and intelligent design in the classroom? What are the strategies, dispositions, tactics, techniques, and workings that are deployed on both sides? Here, as in Foucault's case, we have a network of relations and it is the model of the battle rather than the contract that we might use to study this network that is one of the ruling relations. Power over the curriculum means power over the knowledge that gets taught to future generations. This relationship is an ideal case for studying the microphysics at work.

It would also be of interest to me to know more about individuals' religious experiences and how these contribute to the totality of persons' lives. This would have to be research that goes beyond the simple identification of beliefs, which, because stated in language, always also constitute only a perhaps minor dimension in the totality of an individual life. Much like affect, that which can be articulated in words and that comes to be denoted by the term belief may actually constitute only the iceberg of a rich and variegated aspect of human experiences. Like affect, it may be integral to the unit out of which we understand cognition rather than an external factor, which, as all externalities (Hegel 1807/1969), explains little if anything. It is probably only out of this totality of human experience that we might get closer to the real question always to come about the ultimate foundation of both scientific and religious commitment and experiences.

\section{Coda}

It is quite evident, here and throughout this special issue, that we need a dialogue rather than confrontation to arrive at solutions of contradictions that are in the common interest rather than in the opposition of partial interests that always also involve the politics of power/knowledge where the needs of some are neglected and suppressed at the expense of others. Dialogue does not and cannot overcome the inner contradictions that exist in the fullness of life and that express themselves in external contradiction of its one-sided expressions, here science and religion. What dialogue can bring about is a better understanding, one that is forever to come (Fr. à-venir), always lies in the future (Fr. avenir). Current understandings of equity require us to undo existing inequities and injustice, wherever they become apparent, and to which both science and religion often do not have an answer but often provide fuel and technology to aggravate-as in the paradigm wars between natural and social sciences, the Troubles confronting the Catholics and Protestants in Northern Ireland, genocide in Rwanda, or the bloody conflict over Palestine. Dialogue is precisely the means to deal with difference between science and religion, but much more work may be needed to get all stakeholders to commit to dialogic forms of inquiry, which is in fact what several commentators to the Staver feature article request.

\section{References}

Bakhtin, M. M. (1993). Toward a philosophy of the act. Austin: University of Texas Press. Bateson, G. (1980). Mind and nature: A necessary unity. New York: Bantam. 
Blanchot, M. (1959). Le livre à venir. Paris: Gallimard.

Canadian Broadcasting Corporation (CBC). (2009). Science minister's coyness on evolution worries scientists. Accessed April 10, 2009 at http://www.cbc.ca/canada/newfoundland-labrador/story/2009/03/ 17/tech-090317-gary-goodyear-evolution.html?ref=rss.

Deleuze, G., \& Guattari, F. (1987). A thousand plateaus: Capitalism and schizophrenia. Minneapolis: University of Minnesota Press.

Durkheim, É. (1897-1898). De la définition des phénomènes religieux. Année sociologique, 2, 1-28. Accessed April 9, 2009 at http://social-sciences-and-humanities.com/online/?q=node/361.

Foucault, M. (1975). Surveiller et punir: Naissance de la prison. Paris: Gallimard.

Hegel, G. W. F. (1807/1969). Werke Band 3. Frankfurt: Suhrkamp.

Kant, I. (1956). Werke IV. Wiesbaden: Insel-Verlag.

Marx, K., \& Engels, F. (1969). Werke, Band 3. Berlin: Dietz-Verlag.

Müller, A. M. K. (1974). Naturgesetz, Wirklichkeit, Zeitlichkeit. In E. von Weizsäcker (Ed.), Offene Systeme I: Beiträge zur Zeitstruktur von Information, Entropie und Evolution (pp. 303-358). Stuttgart: Klett-Verlag.

Müller, A. M. K. (1981). Geschöpflichkeit als Herausforderung an Naturwissenschaft und Theologie. In K. Maurin, K. Michalski, \& E. Rudolph (Eds.), Offene Systeme II: Logik und Zeit (pp. 299-326). Stuttgart: Klett-Verlag.

Newfoundland and Labrador Department of Education. (N\&LDoE). (2009). Program of studies 2008-2009. St. John's: Government of Newfoundland and Labrador.

Ontario Ministry of Education (OMoE). (2009). Education about religion in Ontario public elementary schools. Accessed April 10, 2009 at http://www.edu.gov.on.ca/eng/document/curricul/religion/religioe. html.

Roth, W.-M., \& Alexander, T. (1997). The interaction of students' scientific and religious discourses: Two case studies. International Journal of Science Education, 19, 125-146.

Vygotsky, L. S. (1978). Mind in society: The development of higher psychological processes. Cambridge, MA: Harvard University Press.

Vygotsky, L. S. (1986). Thought and language. Cambridge, MA: MIT Press.

\section{Author Biography}

Wolff-Michael Roth is Lansdowne Professor of Applied Cognitive Science at the University of Victoria. His main interest is the study of knowing and learning across the entire lifespan, which he investigates using a pluridisciplinary approach. His recent publications include Dialogism: A Bakhtinian Perspective on Science Language and Learning (Sense Publisher 2009) and the edited volume Science Education from People for People: Taking a Stand(Point) (Routledge 2009). 